\title{
Lights and Shadows of Cyclophosphamide in the Treatment of Multiple Sclerosis
}

\author{
Francesco Patti and Salvatore Lo Fermo \\ Department of Neuroscience, University of Catania, Catania, Italy \\ Correspondence should be addressed to Francesco Patti, patti@unict.it \\ Received 28 October 2010; Revised 29 December 2010; Accepted 19 January 2011 \\ Academic Editor: D. N. Bourdette
}

Copyright ( $) 2011$ F. Patti and S. Lo Fermo. This is an open access article distributed under the Creative Commons Attribution License, which permits unrestricted use, distribution, and reproduction in any medium, provided the original work is properly cited.

Cyclophosphamide (cy) is an alkylating agent used to treat malignancies and immune-mediated inflammatory nonmalignant processes. It has been used as a treatment in cases of worsening multiple sclerosis (MS). Cy is currently used for patients whose disease is not controlled by beta-interferon or glatiramer acetate as well as those with rapidly worsening MS. The most commonly used regimens involve outpatient IV pulse therapy given with or without corticosteroids every 4 to 8 weeks. Side effects include nausea, headache, alopecia, pain, male and women infertility, bladder toxicity, and risk of malignancy. Previous studies suggest that cy is effective in patients in the earlier stages of disease, where inflammation predominates over degenerative processes. Given that early inflammatory events appear to correlate with later disability, a major question is whether strong anti-inflammatory drugs, such as cy, will have an impact on later degenerative changes if given early in the disease to halt inflammation.

\section{Introduction}

Multiple sclerosis (MS) is an acquired inflammatory immune-mediated disorder of the central nervous system, characterized by inflammation, demyelination, and primary or secondary axonal degeneration. It clinically manifests with signs of multiple neurological dysfunctions, followed by recovery or increasing disability. Cyclophosphamide (cy) (the generic name for Endoxan, Cytoxan, Neosar, Procytox, and Revimmune), also known as cytophosphane, is a nitrogen mustard alkylating agent from the oxazophorine group (Figure 1). An alkylating agent adds an alkyl group $\left(\mathrm{C}_{\mathrm{n}} \mathrm{H}_{2 \mathrm{n}+1}\right)$ to DNA. It attaches the alkyl group to the guanine base of DNA, at number 7 nitrogen atom of the imidazole ring. This leads to the synthesis of aberrant couples of cytosin-tymine. The DNA reparation system of the cells removes the modified guanine, triggering cell apoptosis. $\mathrm{Cy}$ is converted by mixed function oxidase enzymes in the liver to active metabolites. The main active metabolite is 4-hydroxycyclophosphamide, which exists in equilibrium with its tautomer, aldophosphamide. Most of the aldophosphamide is oxidised by the enzyme aldehyde dehydrogenase
(ALDH) to make carboxyphosphamide. The intracellular level of this enzyme has been shown to be directly related to cellular resistance to activated cy and is believed to be important in the survival of cells capable of repopulating marrow in autologous bone marrow transplant procedures [1]. Both hematopoietic progenitors and intestinal crypt stem cells display high levels of cytosolic ALDH and are accordingly relatively resistant to cy. Tumor cell resistance to cy may also result from high cytosolic ALDH levels [2]. A small proportion of aldophosphamide is converted into phosphoramide mustard and acrolein. Acrolein is toxic to the bladder epithelium and can lead to hemorrhagic cystitis [3].

Cy and the related nitrogen mustard-derived alkylating agent ifosfamide were developed by Norbert Brock and ASTA (now Baxter Oncology). Brock and his team synthesised and screened more than 1,000 candidate oxazaphosphorine compounds. They converted the base nitrogen mustard into a nontoxic "transport form". This transport form was a prodrug, subsequently actively transported into the cancer cells. Once in the cells, the prodrug was enzymatically converted into the active, toxic form. 
Cy is widely used, together with other antineoplastic drugs, for the treatment of leukemias, lymphomas, and carcinomas but also for the treatment of immune mediated diseases such as vasculitis (Wegener's granulomatosis, polyarteritis nodosa) $[4,5]$, kidney diseases (lupus nephritis idiopathic nephrotic syndrome) [6], and for the treatment of severe systemic-onset juvenile rheumatoid arthritis [7] and interstitial lung disease associated with collagen vascular diseases [8]. Cy is also used for neurological diseases such as refractory cases of polymyositis or inflammatory neuropathies $[9,10]$.

Cy was first tested in MS in 1966 [11]. Even if it is not a drug licensed for MS, due to the lack of adequate phase III studies, cy has been used for the treatment of selected MS patients who have had a partial response to previous treatment with the FDA-approved drugs. Furthermore, we think that cy could have been partially ignored by researchers and pharmaceutical companies due to the low cost of the drug. This could partly explain the lack of adequate randomized controlled studies.

This paper will focus on the results obtained with cy to treat MS patients. In addition, it will report the different protocols of cy use, highlighting results and side effects.

\section{Immunologic Effects}

In the experimental autoimmune encephalomyelitis (EAE) mouse system, two distinct $\mathrm{T}$ cell subsets have been defined. Th1 cells secrete IL- 2 and IFN- $\gamma$ and mediate delayed-type hypersensitivity, whereas Th2 cells secrete predominantly IL4 , IL-5, and IL-10 and mediate humoral immunity $[12,13]$. Cells that secrete predominantly TGF- $\beta$ have been termed Th3 or T-reg cells $[14,15]$, while cells that secrete IL-17, IL21, and IL-22 have been termed Th17. In the EAE mouse model, $\mathrm{T}$ cells producing Th1 cytokines can transfer disease $[16,17]$, while spontaneous recovery from EAE correlates with a switch to TGF- $\beta$ and Th2 cytokines [18-20].

MS is considered to be mediated by T helper type- 1 (Th1) cells [21-23]. In humans, increased production of interferon- $\gamma$ (IFN- $\gamma$ ) by peripheral blood mononuclear cells (PBMCs) has been shown to precede clinical attacks [24], and injection of recombinant IFN- $\gamma$ induces exacerbations of the disease in patients with MS [25]. Cy acts on cellmediated and humoral immunity through its effects on both $\mathrm{T}$ and $\mathrm{B}$ cells. It has been shown to enter the nervous system, as it can be recovered from the cerebrospinal fluid of treated multiple sclerosis patients [26, 27]. Among the FDA-approved drugs, currently used in MS, only fingolimod crosses the blood brain barrier and may, therefore, have direct effects on the CNS [28]; the relationship between cladribine (experimental drug) and the blood brain barrier is unclear, the concentration of cladribine in the cerebrospinal fluid is around $25 \%$ of what is available at the plasma level in patients without CNS disease [29]. Earlier studies in MS patients treated with cy had demonstrated a lymphopenia induced by cy involving both $\mathrm{T}$ and $\mathrm{B}$ cells $[30,31]$ with a more pronounced effect on CD4 cells $[32,33]$. More recent studies showed that cy could also have selective effects on the immune system. Specifically, it increases Th2 cytokine

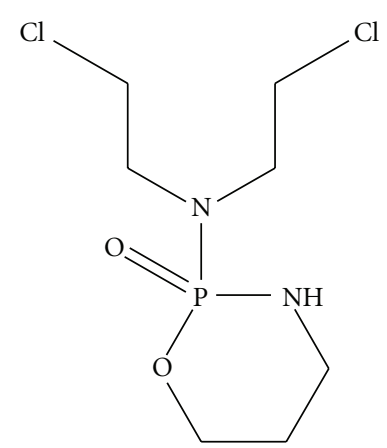

Figure 1

such as IL-4, IL-5, IL-10, and TGF- $\beta$, a cytokine secreted by regulatory $\mathrm{T}$ cells (T-reg), and for this reason, cy is associated with eosinophilia [34]. Patients treated with cy showed an increased frequency of both MBP and PLP cells secreting IL-4 [35], while this effect was not observed in tetanus-toxoid-secreting cells and in MS patients treated with methylprednisolone [36].

The preferential shift towards a Th2-type pattern was also seen in terms of chemokine receptor expression. Chemokine receptors have been found to differentiate between polarized T helper type-1 (Th1) and type-2 (Th2) lymphocytes. The chemokine receptors CCR5 and CXCR3 are expressed primarily on Th1 cells and CCR3, CCR4, and CCR8 on Th2 cells. Previous studies of the expression of chemokine receptors in MS showed that active MS plaques are infiltrated by CCR5+ and CXCR3 + T cells that are major producers of IFN- $\gamma$. In MS patients, cy induced a marked increase in the percentage of CCR $4+\mathrm{T}$ cells that produced high levels of IL- 4 and reversed the increase in the percentages of IFN- $\gamma$ producing CCR5+ and CXCR3+ CD8+ T cells [37].

IL-12 is a heterodimeric cytokine produced mostly by phagocytic cells and induces cytokine production, primarily IFN- $\gamma$, from T cells. Several studies in humans $[38,39]$ and in mice $[40,41]$ have assigned a role to IL-12 (linked to IL-23 and IL-17) as the promoter of Th1 cell generation, acting in antagonism with IL-4, the major promoter of Th2 responses. Administration of IL-12 to mice after the transfer of encephalitogenic cells resulted in increased severity and duration of EAE; treatment with anti-IL-12 antibodies substantially reduced the incidence and severity of adoptively transferred EAE [42]. Elevated serum levels of IL-12 as well as an increase in T cell receptor-mediated IL-12 secretion have been reported in the chronic progressive form of MS [43, 44]. The results of these studies suggest that IL-12 could play an important role in the pathogenesis of EAE and MS.

In patients treated with methotrexate, methylprednisolone, or cy/methylprednisolone, only the last treatment normalized the elevated IL-12 production. Patients followed prospectively before and after starting CY/MP treatment, in fact, showed a gradual decrease in IL-12 and IFN- $\gamma$ production and an increase in IL-4 and IL-5 $[45,46]$.

In summary, probably a Th1-type cytokine bias has a role in the pathogenesis of the disease and is reversed by cy/MP treatment with an associated Th2 and TGF- $\beta$ (Th3Treg) type response. 


\section{Clinical Data}

Several reports have been published on the clinical effects of cy in MS. Many reports showed that cy is effective in MS, but not all studies have shown positive effects. La Mantia et al. in 2007 conducted an evaluation of the published studies performed on cy in MS. Of the 326 identified references, 80 were selected for full review and only four RCTs were selected for the final analysis. The authors concluded that intensive immunosuppression with cy (alone or associated with ACTH or steroids) in patients with progressive MS compared to placebo or no treatment (152 participants) did not prevent the long-term (12-18-24 months) risk of evolution to a next step of the EDSS. However, the authors suggested that the lack of efficacy in progressive MS does not lead to the conclusion that the drug is not effective in the inflammatory phase of the disease [47]. Cy, in fact, is considered a treatment option in several recently published MS treatment guidelines [48]. However, a major question for physicians treating patients with MS is how cy should be used to obtain the best results and to avoid side effects. As we will see in the following paragraphs, the studies conducted since 1966 in MS patients give us some answers.

\section{Early Studies}

The first clinical trial with cy was published at the end of the 1950s [49].

In 1966, Aimard et al. described the arrest of the disease observed in a progressive case of MS using cy [11]. In subsequent years, the effects of the drug on patients with a progressive form of the disease (Table 1) were described [5055]. In 1975, Drachman et al. observed no effects using 4$5 \mathrm{mg} / \mathrm{kg}$ of cy given for 10 successive days for the treatment of acute attacks (see Table 1) [56]. In 1977, Gonsette et al. described, in an open-label, uncontrolled study, the results obtained with cy in 201 relapsing/remitting patients [57] (Table 1). It is interesting to note that more positive effects were observed in those patients with the shortest length of disease; on the contrary, more severely disabled patients did not benefit from cy treatment. In 1983, the first clinical trial with a rigorous design (randomized and controlled trial) was performed to evaluate the clinical effects of cy in MS patients. Hauser et al. [58] evaluated patients with progressive MS treated with a 2- to 3-week course of cy, intravenously 400$500 \mathrm{mg} /$ day, to achieve leukopenia of $2000 / \mathrm{mm}^{3}$ plus ACTH compared to a similar group treated with ACTH alone and to a group that received plasma exchange, $\mathrm{ACTH}$, and oral cy. The results showed that $80 \%(16 / 20)$ of the cy-treated patients had improved or were stable at 1 year compared to only $20 \%(4 / 20)$ in the ACTH-treated group. The plasma exchange group showed an intermediate $(50 \%)$ response. Positive clinical results were observed on disability with a very low number of treatment failures. Moreover, analysis of the patient profiles demonstrated that the patients who were relatively young (35 years) and with a short disease duration (between 2 and 3 years) were the best clinical responders. It was also reported that $11 / 20(55 \%)$ patients who were stable or who had improved at the 1-year follow-up experienced reprogression of their disease in the second or third year after treatment suggesting that a short period of treatment was not sufficient. In 1993, the Northeast Cooperative Treatment Group demonstrated that patients between 18 to 40 years old receiving cy boosters every other month for 2 years, did not show a reprogression of the disease and that there were no differences between the modified induction regimen and the previous published regimen to prevent or delay disease reprogression [59]. This study led the way for currently used protocols in which treatment is given as outpatient pulses similar to lupus nephritis treatment.

The Northeast Cooperative Study results were challenged by the results obtained with cy, on patients with progressive MS, from the Canadian Cooperative Multiple Sclerosis group study [60] and by the Kaiser study [61].

The first trial, a single blinded randomized and placebocontrolled multicentre study, included 168 progressive MS patients. The investigators did not find significant differences in time-to-treatment failure, comparing patients treated with intravenous cy and oral prednisone, patients treated with oral cy and oral prednisone on alternate days plus weekly plasma exchange and one further group of patients treated with oral placebo and sham plasma exchange. In the Kaiser study, 22 progressive MS patients received $400-500 \mathrm{mg}$ of cy, IV, 5 days per week, until the leukocyte count fell below $4000 / \mathrm{mm}^{3}$, and were compared to 20 patients receiving folic acid in a randomized, single-blind study. The similar disease progression in the two groups provided evidence of a lack of substantial benefits of cy treatment.

The potential reasons for differences between these two studies and the 1983 NEJM study and the Northeast Cooperative Treatment Group study have been extensively debated in the literature [62-64].

In summary, the studies cited seem to delineate a role for cy in the treatment of patients with an inflammatory component of the disease (early, aggressive, and inflammatory MS). There is evidence of poor or no benefit when cy is administered in both primary and secondary progressive MS patients.

\section{Recent Studies}

In recent years, considering previous studies, most physicians have used cy to treat RR-MS, SP-MS, or rapidly deteriorating MS patients with intermittent intravenous (monthly or bimonthly) pulse therapy, alone or in combination with DMTs, and, less frequently, they have used an induction protocol (see Table 2). Of the several published studies (see Table 1), three must be highlighted because they were performed on patients with aggressive forms of the disease. Weinstock-Guttman et al. described the effects of cy (openlabel) in 17 consecutive patients with "fulminant MS" (defined as a deterioration of more than one and a half points on the EDSS for more than 3 months); after 24 months, $69 \%$ of patients were stable or had improved [65]. Gobbini et al. reported clinical stability in five patients with rapidly deteriorating relapsing-remitting MS who were treated monthly with cy for 6 months and then on alternate 
TABLE 1: Clinical studies of cy in the treatment of MS.

\begin{tabular}{|c|c|c|c|c|c|}
\hline Date & Author & $\begin{array}{c}\text { No. of } \\
\text { patients }\end{array}$ & Type of MS & Regimen & Comments and side effects \\
\hline \multicolumn{6}{|c|}{ Study of cy in to treat the relapse of $M S$} \\
\hline 1975 & Drachman et al. & 6 & Acute attacks & $4-5 \mathrm{mg} / \mathrm{kg}$ IV for 10 successive days & $\begin{array}{l}\text { No effect observed on recovery from } \\
\text { relapse }\end{array}$ \\
\hline \multicolumn{6}{|c|}{ Studies of cy in progressive MS } \\
\hline 1966 & Aimard et al. & 1 & Progressive & & $\begin{array}{l}\text { Arrest of disease in progressive MS } \\
\text { patients, }\end{array}$ \\
\hline 1967 & Girard et al. & 30 & Progressive & $\begin{array}{l}200 \mathrm{mg} / \text { day IV for } 4-6 \text { weeks; ( } 4-9 \mathrm{~g} \\
\text { total) }\end{array}$ & $50 \%$ improved or stable at 2 years \\
\hline 1969 & Millac and Miller & 16 & Progressive & Oral, 75-100 mg/day & $\begin{array}{l}\text { Toxicity associated with low white } \\
\text { blood counts }\end{array}$ \\
\hline 1975 & Hommes et al. & 32 & Progressive & $\begin{array}{l}100 \mathrm{mg} \text { qid }+50 \mathrm{mg} \text { prednisone bid } \\
(8 \mathrm{~g} \text { total over } 20 \text { days })\end{array}$ & $\begin{array}{l}\text { Stabilization in } 69 \% \text { of patients. } \\
\text { Better results were found in patients } \\
\text { with shorter duration of their disease }\end{array}$ \\
\hline 1980 & Hommes et al. & 39 & Progressive & $\begin{array}{l}400 \mathrm{mg} \text { cy }+100 \mathrm{mg} \text { prednisone. } 8 \mathrm{~g} \\
\text { total }\end{array}$ & $\begin{array}{l}\text { Stabilization in } 69 \% \text { of patients. } \\
\text { Open label, uncontrolled }\end{array}$ \\
\hline 1981 & Theys et al. & 21 & Progressive & $6-8$ g given over $3-4$ weeks & $\begin{array}{l}\text { No effect in patients with moderately } \\
\text { advanced MS over } 2 \text { years }\end{array}$ \\
\hline 1983 & Hauser et al. & 20 & Progressive & $\begin{array}{l}400-500 \mathrm{mg} / \text { day IV for } 10-14 \text { days }+ \\
\text { ACTH }\end{array}$ & $\begin{array}{l}16 / 20 \text { stabilized at } 1 \text { year versus } 4 / 20 \\
\text { with ACTH and } 9 \text { out of } 18 \text { with } \\
\text { plasma exchange regimen }\end{array}$ \\
\hline 1987 & Goodkin et al. & 27 & Progressive & $\begin{array}{l}\text { Inpatient induction for } 10-14 \text { days } \\
\text { with IV cy/ACTH or outpatient } \\
\text { induction with } 700 \mathrm{mg} / \mathrm{m}^{2} \text { weekly } \\
\text { for } 6 \text { weeks plus prednisone }\end{array}$ & $\begin{array}{l}\text { Maintenance therapy of } 700 \mathrm{mg} / \mathrm{m}^{2} \\
\text { every } 2 \text { months for } 24 \text { months. } \\
\text { Stabilization in } 59 \% \text { of patients } \\
\text { induced at } 12 \text { months versus } 17 \% \text { in } \\
\text { nonrandomized controls }\end{array}$ \\
\hline 1987 & Myers et al. & 14 & Progressive & $\begin{array}{l}\text { Monthly therapy with } \\
400-800 \mathrm{mg} / \mathrm{m}^{2} \text { oral or IV escalating } \\
\text { to } 1200-2000 \mathrm{mg} / \mathrm{m}^{2} \text { monthly; } 5-13 \\
\text { doses given over } 5-14 \text { months to } \\
\text { reduce B cell and CD } 4+\text { cells. With } \\
\text { and without steroids }\end{array}$ & $\begin{array}{l}3 \text { improved, } 9 \text { unchanged, and } 2 \\
\text { worsened }\end{array}$ \\
\hline 1987 & Siracusa et al. & 14 & Progressive & $\begin{array}{l}\text { Short course of intensive cy until } \\
\text { WBC reached } 3000\end{array}$ & $\begin{array}{l}5 \text { patients discontinued because of } \\
\text { side effects. Patients stable, though } \\
\text { not improved }\end{array}$ \\
\hline 1988 & Carter et al. & 164 & Progressive & 2-week IV cy/ACTH regimen & $\begin{array}{l}81 \% \text { improved or stable at } 1 \text { year. } \\
\text { Reprogression in } 69 \% \text { of patients at } \\
\text { mean of } 17.6 \text { months }\end{array}$ \\
\hline 1989 & Mauch et al. & 21 & Progressive & $\begin{array}{l}8 \mathrm{mg} / \mathrm{kg} \text { IV at } 4 \text {-day intervals until } \\
\text { lymphocyte count was half the initial } \\
\text { value. ( } 1.9 \mathrm{~g} \text { average total dose) }\end{array}$ & $\begin{array}{l}\text { 20/21 patients stable at } 1 \text { year versus } \\
7 / 21 \text { patients receiving ACTH }\end{array}$ \\
\hline 1989 & Canadian & 55 & Progressive & $\begin{array}{l}1 \mathrm{~g} \text { IV on alternate days up to } 9 \mathrm{~g}+ \\
\text { oral prednisone }\end{array}$ & $\begin{array}{l}\text { No difference versus placebo } \\
(n=56) \text { or plasma exchange } \\
\text { regimen. }(n=57)\end{array}$ \\
\hline 1989 & Trouillas et al. & 10 & Progressive & $\begin{array}{l}\text { IV ( } 450 \mathrm{mg} / \text { day) for } 20 \text { days } 3 \text { weeks } \\
+ \text { MP }\end{array}$ & $\begin{array}{l}6 / 10 \text { stabilized at } 3 \text { years versus } 9 / 10 \\
\text { in plasma exchange regimen versus } \\
0 / 10 \text { in untreated or azathioprine } \\
\text { controls }\end{array}$ \\
\hline 1991 & Likosky et al. & 22 & Progressive & $\begin{array}{l}\text { IV (400-500 mg) } 5 \text { days/week until } \\
\text { leukocyte count fell below } 4000 / \mathrm{mm}^{3}\end{array}$ & $\begin{array}{l}\text { No difference versus placebo } \\
(n=21) \text { at } 12,18, \text { or } 24 \text { months }\end{array}$ \\
\hline
\end{tabular}


TABle 1: Continued.

\begin{tabular}{|c|c|c|c|c|}
\hline Date & Author & $\begin{array}{c}\text { No. of } \\
\text { patients }\end{array}$ & Type of MS & Regimen \\
\hline 1993 & Weiner et al. & 256 & Progressive & $\begin{array}{l}\text { IV cy/ACTH induction versus } \\
\text { modified IV cy/ACTH induction } \\
\left(600 \mathrm{mg} / \mathrm{m}^{2} \text { on days } 1,2,4,6,8\right) \\
\text { followed by } 700 \mathrm{mg} / \mathrm{m}^{2} \mathrm{IV} \text { pulses } \\
\text { every } 2 \text { months for } 2 \text { years }\end{array}$ \\
\hline 1998 & La Mantia et al. & 30 & Progressive & $\begin{array}{l}\text { Every } 2 \text { months IV pulses } \\
(600 \mathrm{mg} / \mathrm{m}) \text { for } 12 \text { months with or } \\
\text { without induction }\left(300 \mathrm{mg} / \mathrm{m}^{2} \mathrm{IV}\right. \\
\text { for } 9 \text { days) }\end{array}$ \\
\hline 1999 & Hohol et al. & 95 & Progressive & $\begin{array}{l}\text { Progressive induction with } 1 \mathrm{~g} \text { IV MP } \\
\text { for } 5 \text { days followed by IV pulse } \\
\text { cy/MP every } 1 \text { month for } 1 \text { year, } \\
\text { every } 6 \text { weeks for } 1 \text { year and every } 2 \\
\text { months for } 1 \text { year }\end{array}$ \\
\hline 2003 & Perini et al. & 26 & Progressive & $\begin{array}{l}\text { IV cy/MP } 800-1250 \mathrm{mg} / \mathrm{m}^{2} \text { monthly } \\
\text { for } 1 \text { year then every } 2 \text { months for } 1 \\
\text { year }\end{array}$ \\
\hline 2004 & Zephir et al. & 111 & Progressive & $\begin{array}{l}\text { IV cy/MP } 700 \mathrm{mg} / \mathrm{m}^{2} \text { monthly for } 1 \\
\text { year }\end{array}$ \\
\hline
\end{tabular}

Studies of cy in relapsing-remitting and rapidly deteriorating $M S$

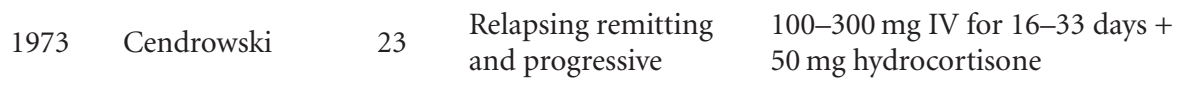

1977 Gonsette et al. $\quad 110 \quad$ Relapsing-remitting

1980 Gonsette et al. $\quad 134 \quad$ Relapsing-remitting

$1988 \quad$ Killian et al. $\quad 14 \quad$ Relapsing-remitting

1990 Millefiorini et al. $\quad 15 \quad$ Relapsing-progressive

1990 D’Andrea et al. $\quad 7 \quad$ Relapsing-remitting

Weinstock-
1997 Guttman et

al.

1999 Gobbini et al. $\quad 5 \quad$ Relapsing-remitting

$2000 \quad$ Manova et al. $\quad 70 \quad$ Relapses

17 "Fulminant"

$2001 \quad$ Khan et al.

\section{IV over 2 weeks to achieve}

leukopenia of 2000 and lymphopenia of $1000 .(1-12 \mathrm{~g})$

IV over 2 weeks to achieve

leukopenia of 2000 and lymphopenia of 1000. (1-12 g)

Monthly $750 \mathrm{mg} / \mathrm{m}^{2}$ IV pulses for 1 year

IV cy followed by booster every 2 months for 2 years

IV induction (11 doses $300 \mathrm{mg} / \mathrm{m}^{2}$ ) then every 6 months for 3 years

IV $500 \mathrm{mg} / \mathrm{m}$ + IV MP for 5 days followed by maintenance therapy with cy/methotrexate, MP or IFN-beta-1b

Monthly pulses of CTX

$\left(1000 \mathrm{mg} / \mathrm{m}^{2}\right)$ given for $12 \mathrm{months}$

IV MP (200 mg) every other day for 10 doses versus IV cy (200 mg) on alternate days for 10 doses and then monthly for 3 months (total dose: $2.6 \mathrm{~g}$ )

Pulse cy $1000 \mathrm{mg} / \mathrm{m}^{2}$ given monthly plus $20 \mathrm{mg}$ IV dexamethasone
Comments and side effects

No difference between published or modified induction (56\% stable at 12 months). Benefit of booster versus no boosters at 24 and 30 months

At 12 months $75 \%$ stable if induction given; $35 \%$ stable if no induction

Response to therapy linked to duration of disease

Clinical improvement at 2 years/reduction in $\mathrm{Gd}+$ lesions and T2 lesion volume

Response in patients with clinical attack in the 2 years prior to therapy

No difference in comparison to patients treated with ACTH or cortisol

Stabilization in $62 \%$ of patients over 2-4 years. Decrease in relapse rate

Stabilization in relapse rate in $76 \%$ of patients

A trend showing decreased relapses in 6 treated patients versus 8 placebo patients

$50 \%$ clinically stable at 2 years. No major side effects

Decrease relapse rate in all patients at 1 year; in the following 2 years, 2 patients worsened, and others were clinically stable

13/17 (75\%) patients improved or were stable at 12 months; $9 / 13(69 \%)$ at 24 months

MRI outcome: decrease in Gd+ lesions following pulse CTX in all patients treated

At 12 months EDSS improved in CTX-treated group versus MP group. No difference between groups at 1 month

Clinical improvement or stability in $14 / 14$ patients at 6 months sustained at 18 months following treatment 
Table 1: Continued.

\begin{tabular}{|c|c|c|c|c|c|}
\hline Date & Author & $\begin{array}{c}\text { No. of } \\
\text { patients }\end{array}$ & Type of MS & Regimen & Comments and side effects \\
\hline 2001 & Patti et al. & 10 & $\begin{array}{l}\text { Rapidly progressive } \\
\text { IFN- } \beta \\
\text { nonrespondents }\end{array}$ & $\begin{array}{l}\text { Monthly pulses cy } 500-1500 \mathrm{mg} / \mathrm{m} \\
\text { for } 18 \text { months }\end{array}$ & $\begin{array}{l}\text { Reduction in relapses, disability plus } \\
\text { T2 MRI burden }\end{array}$ \\
\hline 2002 & Smith et al. & 58 & $\begin{array}{l}\text { Rapidly deteriorating } \\
\text { refractory patients }\end{array}$ & $\begin{array}{l}3 \text { days IV MP followed by monthly } \\
\text { pulses of MP or MP/cy }\left(800 \mathrm{mg} / \mathrm{m}^{2}\right) \\
\text { for } 6 \text { months }\end{array}$ & $\begin{array}{l}\text { Less Gd+ lesions at } 3 \text { and } 6 \text { months in } \\
\text { CTX/MP versus MP treated subjects }\end{array}$ \\
\hline 2004 & Patti et al. & 10 & $\begin{array}{l}\text { Clinical and MRI } \\
\text { follow-up } 36 \text { months } \\
\text { after the } \\
\text { discontinuation of cy } \\
\text { in previous reported } \\
\text { patients }\end{array}$ & $\begin{array}{l}\text { Monthly pulses cy } 500-1500 \mathrm{mg} / \mathrm{m} \\
\text { for } 18 \text { months }\end{array}$ & $\begin{array}{l}\text { Maintenance of the results obtained } \\
\text { in relapse rate, EDSS, T2 MRI total } \\
\text { lesion load and T2 lesions number }\end{array}$ \\
\hline 2005 & Reggio et al. & 30 & $\begin{array}{l}\text { Rapidly progressive } \\
\text { IFN- } \beta \\
\text { nonrespondents }\end{array}$ & $\begin{array}{l}500-1500 \mathrm{mg} / \mathrm{m}^{2} \text { combined with } \\
\text { INF- } \beta\end{array}$ & $\begin{array}{l}\text { Reduction in relapses plus } \mathrm{Gd}+\mathrm{MRI} \\
\text { burden }\end{array}$ \\
\hline 2005 & de Bittencourt PR & 1 & Rapidly progressive & IV cy/MP $3800 \mathrm{mg}$ accidentally given & Long term remission ( 7 years) \\
\hline 2006 & Gladstone & 12 & $\begin{array}{l}\text { Deteriorating and RR } \\
\text { and SP MS patients }\end{array}$ & $200 \mathrm{mg}$ per kg over 4 days & $\begin{array}{l}\text { No patients increased their baseline } \\
\text { EDSS score more than } 1.0 \text {, } \\
\text { improvement in quality of life after } \\
15 \text { months }\end{array}$ \\
\hline 2008 & Krishman et al. & 21 & $\begin{array}{l}\text { MS patients with } \\
\text { "active" MRI or } \\
\text { relapse or EDSS } \\
\text { deterioration in the } \\
\text { year before }\end{array}$ & $50 \mathrm{mg} / \mathrm{kg} /$ die for 4 consecutive days & $\begin{array}{l}\text { Reduction of EDSS and of the } \\
\text { number of Gd+ lesions at end of } \\
\text { follow-up ( } 24 \text { months) }\end{array}$ \\
\hline 2009 & Patti et al. & 20 & $\begin{array}{l}\text { Active RR MS patients } \\
(>1 \text { relapse in the } \\
\text { prior } 12 \text { months and } \\
>1 \text { Gd+ MRI lesion) }\end{array}$ & $\begin{array}{l}\text { Monthly cy, administered to induce a } \\
\text { leucopoenia below } 1000 \times \mathrm{mm}^{3} \text {, plus } \\
\text { methylprednisolone (MP) } 1 \mathrm{~g} \text { for } 12 \\
\text { months followed by IFN- } \beta \text { for a } \\
\text { further } 12 \text { months (cy group); versus } \\
\text { IFN- } \beta \text { alone for } 2 \text { years (IFN- } \beta \\
\text { group) }\end{array}$ & $\begin{array}{l}\text { Reduction of relapse rate and of the } \\
\text { number of gadolinium-enhancing } \\
\text { lesions at end of follow-up ( } 24 \\
\text { months). Relapse-free patients at the } \\
\text { second year were } 80 \% \text { in the cy group } \\
\text { versus } 40 \% \text { in the IFN- } \beta \text { group }\end{array}$ \\
\hline 2009 & Perumal et al. & 26 & $\begin{array}{l}\text { Active RR MS patients } \\
\text { (at least two relapse in } \\
\text { the year before) }\end{array}$ & & \\
\hline
\end{tabular}

Study of cy in pediatric MS

2009 Makhani et al. $\quad 17 \quad \begin{aligned} & \text { Children with MS } \\ & \text { with multiple relapses } \\ & \text { or EDSS deterioration }\end{aligned}$

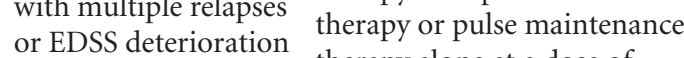
in the year before

Induction therapy alone, induction therapy with pulse maintenance therapy alone at a dose of $600-1000 \mathrm{mg} / \mathrm{m}^{2}$
After 1 year of treatment reduction in relapse rate and a stabilization of disability months. These results were confirmed by a rapid reduction in gadolinium-enhancing lesions, seen with monthly brain MRI scans [66]. Khan et al. reported an open-label study of intravenous cy given monthly to 14 patients with relapsingremitting MS who were rapidly deteriorating (defined as a greater than three-point increase in the EDSS score in the previous 12 months despite DMT therapy and intravenous prednisone) [67]. Some authors have used, accidentally or intentionally, high doses of cy. A report of a single patient with relapsing remitting MS who, on one occasion, accidentally received a dose of $3800 \mathrm{mg}$ of the drug showed no evidence of clinical or MRI disease activity for the next 7 years [68]. An open-label study by Gladston and coworkers, with high doses of cy (200 mg per $\mathrm{kg}$ over 4 days), in 13 patients with treatment-refractory MS showed significant disease stability (no patients increased their baseline EDSS score by more than 1.0) and improvement in quality of life after 15 months [69]. Also, Krishman and coworkers described the effects of high doses of cy after 24 months in 21 patients with RR-MS with "active" MRI or clinical exacerbation in the year before or a worsening EDSS score of 1 point or higher compared to the preceding year using an immunoablative regimen of $50 \mathrm{mg} / \mathrm{kg} /$ day for 4 consecutive days followed by granulocyte colony stimulating factor 
(GCS) 6 days after cy. They observed a reduction of the EDSS score and of the number of gadolinium-enhancing lesions at the end of follow-up [70]. Makhani and coworkers reviewed their multicentre experience with cy in the treatment of 17 children with MS. After 1 year of treatment they observed a reduction in relapse rate and a stabilization of disability scores [71].

\section{Comparison Studies}

Zipoli et al. compared the efficacy and safety of intravenous cy and mitoxantrone as second-line therapy in relapsingremitting or secondary-progressive MS patients. Mitoxantrone was administered at a dosage of $8 \mathrm{mg} / \mathrm{m}^{2}$ monthly for 3 months, then every 3 months, until a dosage of $120 \mathrm{mg} / \mathrm{m}^{2}$ was reached. Cy was administered at a dosage of $700 \mathrm{mg} / \mathrm{m}^{2}$ monthly for 12 months, then bimonthly for a further 24 months. Seventy-five patients received mitoxantrone (31 RR, $44 \mathrm{SP}$ ) and $78 \mathrm{cy}$ (15 RR, $63 \mathrm{SP})$. The two groups differed only in terms of a significantly higher proportion of RR patients in the mitoxantrone group. After a mean follow-up of 3.6 years, the authors observed a lack of a significant difference in terms of time to the first relapse, whereas time to disease progression was slightly shorter in the group treated with mitoxantrone than in the cy group. After 12 months of treatment, active MRI scans were reduced by $69 \%$ in the mitoxantrone group and $63 \%$ in the cy group of patients. Discontinuation due to side effects was more frequent in cy patients, but the authors concluded that the overall tolerability of the two treatments was acceptable [72]. Gallo et al. treated fifty secondary progressive MS patients, who had lost one or more EDSS points in the prior two years, with cy (25 patients, mean disease duration 13.3 years; mean EDSS score at study entry: 5.7) or mitoxantrone ( 25 patients, mean disease duration: 11.5 years; mean EDSS score at study entry: 5.5). SPMS patients were treated for two years. The authors observed a significant reduction in both groups of relapse rate and disability progression. Subgroups of mitoxantrone- and cyresponding patients were characterized by a significantly shorter duration of the secondary progressive phase of the disease. In these subgroups, the improvement in the EDSS score at the end of therapy was higher than the remaining patients. The safety profiles of both drugs were acceptable; however, the authors also evaluated the cost of the two treatments and concluded that the cy-based therapy protocol was significantly less expensive [73].

\section{Our Experience}

Our group reported on the effectiveness of a combination of cy and beta-interferon in patients with rapidly progressive or "transitional" MS (characterized by frequent and severe attacks plus worsening on the disability status scale). We treated 10 such patients with monthly pulses of IV cy (500$1500 \mathrm{mg} / \mathrm{m}^{2}$ ) to obtain a lymphopenia of between 600 and $900 / \mathrm{mm}^{3}$ for 12 consecutive months and then at 2 -month intervals for a further 6 months. We found a significant reduction in the number of relapses, disability and T2 MRI burden of disease with a stabilization of the disease for a mean of 36 months after the discontinuation of cy treatment $[74,75]$. We found that the treatment was safe and well tolerated. In the following years, we replicated this result in a cohort of thirty rapidly deteriorating MS patients treated for 24 months with cy $\left(500-1500 \mathrm{mg} / \mathrm{m}^{2}\right)$ combined with INF- $\beta$ [76].

In a randomised, multicentre trial of 59 patients with relapsing-remitting MS, who did not respond to interferon beta, Smith et al. observed that the combination of cy and interferon beta-1a reduced the clinical disease activity and gadolinium-enhancing MRI lesions in the brain [77]. In 2009, our group reported the effects of cy as initial induction therapy in "active" MS. Forty active relapsingremitting MS patients ( $>1$ relapse in the prior 12 months and $>1 \mathrm{Gd}+$ MRI lesion) were randomized in two groups of twenty to receive monthly cy, designed to induce a leucopenia below $1000 \times \mathrm{mm}^{3}$, plus methylprednisolone (MP) $1 \mathrm{~g}$ for 12 months followed by IFN- $\beta$ for a further 12 months versus IFN- $\beta$ alone for 2 years. The annual relapse rate was reduced from 1.9 observed at baseline to 0.1 in the cy group versus 0.5 in the interferon group $(P=.02)$ at Year 2; relapse-free patients at the second year were $80 \%$ of the cy group versus $40 \%$ of the IFN group $(P=.024)$; and the percentage of patients without Gd+ MRI lesions at 24 months was $90 \%$ in the cy group versus $54 \%$ in the IFN group-2 $(P=.04)$. No serious adverse events were observed during follow-up. This study supports the concept of using cy as an induction treatment for improving the impact of IFN over time [78]. A similar approach was used by Perumal et al. They used cy as the initial therapy in patients who had not received DMT therapy before. All patients had experienced at least two relapses in the year prior to therapy. Twenty-six patients received monthly intravenous cy for 6 months followed by initiation of immunomodulatory therapy. At year 1, the mean EDSS score, relapse rate, and Gd-enhancing per patient at baseline were reduced from 3.61 to $2.22,3.42$ to 0.77 , and 3.55 to 0.33 , respectively. These studies suggest that cy may be used as initial therapy in relapsing-remitting MS patients [79].

\section{Cy in Autologous Haematopoietic Stem-Cell Transplantation (AHSCT) for MS}

Intense immunosuppression using cy $1.5-4 \mathrm{~g} / \mathrm{m}^{2}$ total dose over 1-2 days, to mobilize peripheral blood hematopoietic stem cells (HSC), followed by a conditioning regimen, and then autologous haematopoietic stem-cell transplantation (AHSCT) has been evaluated as a possible new therapeutic tool in severe autoimmune disorders, after it was shown to be efficacious in animal models of immunomediated diseases [80]. The conditioning regimen, the second step of the procedure, could be carried out with several protocols, the most common protocol used is the BEAM regimen which includes $300 \mathrm{mg} / \mathrm{m}^{2}$ carmustine at day-7, $200 \mathrm{mg} / \mathrm{m}^{2}$ etoposide and $200 \mathrm{mg} / \mathrm{m}^{2}$ cytarabine from day- 6 to day-3, and $140 \mathrm{mg} / \mathrm{m}^{2}$ melphalan at day-2. These drugs cross the blood-brain 
TABLE 2: Treatment regimens.

(a) IV induction therapy: $600 \mathrm{mg} / \mathrm{m}^{2}$ CTX given on days 1, 2, 4, 6, 8 plus MP given daily for 8 days.

(b) IV pulse therapy with CYX/MP: CTX pulses starting at $800 \mathrm{mg} / \mathrm{m}^{2}$ with dose augmentation in order to obtain a leukopenia of $3000 / \mathrm{mm}^{3}$ and a lynphocitopenia of $800 / \mathrm{mm}^{3}$; every 4 weeks x $18-24$ months, every 2 months $\times 24.1 \mathrm{~g}$ MP given with CTX.

(c) Pulse therapy with CTX at a fixed dose: CTX pulses given at $800-1000 \mathrm{mg} / \mathrm{m}^{2}$ every $4-8$ weeks for $12-24$ months, given with or without MP.

(d) Combination therapy: IV pulse CTX therapy given concomitantly with beta-interferon or glatiramer acetate in nonresponders.

barrier and possibly hit the autoreactive clones that colonize the CNS. In North America and also in Europe, total body irradiation (TBI) plus cy is frequently used. Another conditioning regimen utilized in the reported studies is BCNU $300 \mathrm{mg} / \mathrm{m}^{2}$ plus cy $150-200 \mathrm{mg} / \mathrm{kg}$, an intermediate intensity regimen, which eliminates etoposide and ARA$\mathrm{C}$ from the BEAM scheme. Less intense regimens, with a prevalence of immunosuppressive and minor myeloablative effects, such as cy $200 \mathrm{mg} / \mathrm{kg}$ plus alemtuzumab (Campath) or ATG, have been recently utilized, considering that they might provide a satisfactory clinical outcome with lower toxicity. The effects of AHSCT on the number of relapses are considerable; they are usually dramatically reduced; this anti-inflammatory activity is corroborated by the effects of AHSCT on MRI parameters, with the absence of gadolinium enhancing lesions on MRI inflammatory activity in most cases for a period of at least $1-3$ years.

The main problem of AHSCT is the transplant-related mortality (TRM), which is around 3.3\%. The mortality risk is mainly due to infections which can occur during the aplastic phase which follows the conditioning regimen and are related to the intensity of the therapies used [81-85].

\section{How to Use Cy: What We Have Learned from Previous Studies and Our Experience}

Over the last few years, the use of cy in MS has evolved towards the use of intermittent pulse therapy given monthly or bimonthly over a 1- to 3-year period administered intravenously with an adjusted dose to obtain a leucopoenia target or with a fixed dose (Table 2, regimen (b) and (c) respectively). In our experience after the first dose, (usually we start with a dose of $800 \mathrm{mg} / \mathrm{m}^{2}$ ), a dose modulation is made on the basis of the number of white blood cells observed at the nadir of leukopenia (after 12-14 days of administration). Our target is to keep the white blood cells below 3000 for mmc and lymphocytes below 800 for mmc. In our opinion, this target is related to a good balance between effectiveness and safety. Antiemetic drugs and iv steroids are usually administered and large amount of fluids are also administered during the same session of therapy. In treated patients, we further administer iv MESNA (with a dose equal to $20 \%$ of the dose of cy) before the cy booster and four hours after the administration of the drug. We also suggest that the patient should drink a lot (at least two litres of fluids) in the two days following treatment. MESNA is used therapeutically to reduce the incidence of hemorrhagic cystitis and hematuria when a patient receives cy. MESNA assists the neutralization of the urotoxic metabolites derived from the metabolism of cy by binding them through their sulfhydryl group and also increases urinary excretion of cysteine [86].

\section{When to Use Cy: What We Have Learned from Previous Studies and Our Experience}

Collectively, data from studies indicate that patients with rapidly worsening, treatment refractory, relapsing-remitting MS, or in an early secondary progressive phase of the disease might benefit from treatment with intravenous cy. We think that in selected patients the drug should be considered when there are reasons that do not allow use of fingolimod or natalizumab. Little or nothing appears to be effective in primary progressive forms of MS. In order to turn off inflammation from the beginning of the disease, an innovative approach could be (supported by the knowledge about MS pathogenesis), in selected patients, a short early treatment of 12-24 months with cy, followed by an immunomodulator drug. This approach could be, in our opinion, a reasonable treatment for a young patient, suffering from RR-MS with a short disease duration, who shows an "active" clinical disease, characterized by several relapses over a short period of time (for RR-MS patients) and/or active MRI disease (defined as either new T2 lesions or T1 gadolinium enhancing lesions). We can further consider the option to treat as early as possible, immediately in patients with a clinically isolated syndrome, with a higher T2 lesion load and gadolinium enhancing lesions. It is conceivable that the induction with a more potent agent (cy, mitoxantrone, natalizumab, alemtuzumab, fingolimod, and cladribine) followed by a less potent drug (interferons, GA) may "freeze" and stabilize the disease. The relatively short period of induction with cy allows us to use cumulative doses which are largely below the tolerated cumulative dose of 80 $100 \mathrm{~g} /$ lifetime. Thus, if after 5-10 or more years patients tend to reprogress, there exists the option to treat with cy again for some time.

\section{Toxicity}

The toxic effects of cy in the treatment of neoplastic or immunomediated diseases are well known [87]. The most frequent serious adverse event is hemorrhagic cystitis $[88,89]$. Cases of bladder cancer have been observed in patients who have received long-term cy treatment [90]. For these, reasons long-term oral cy has been avoided in MS. 
TABLE 3: Data obtained from 200 MS patients treated with cy in our centre over a ten-year period. ${ }^{*}$ of the fertile women.

\begin{tabular}{lc}
\hline Side effects & $\%$ \\
\hline Nausea and vomit & 40 \\
Amenorrhea & $18^{*}$ \\
Transitory amenorrhea & $60^{*}$ \\
Transitory azoospermia & 60 \\
Headache & 15 \\
Alopecia (reversible) & 13 \\
Fatigue & 10 \\
Diffuse pain & 8 \\
Cutaneous rash & 6 \\
Gastritis and diarrhoea & 6 \\
Bladder toxicity & 6 \\
Infection & 3 \\
Cancer risk & 1 \\
Arrhythmia & 1 \\
Dyspnoea & 0.5 \\
\hline
\end{tabular}

Gonadal failure occurs in both men and women receiving alkylating agents such as cy. Most of the available data concerns the rate of ovarian failure in cancer survivors. However, in these patients, alkylating agents were used as part of a multidrug regimen and at different doses than for immunologic diseases. As concerns the use of cy in immunemediated disease, in a lupus nephritis trial, after 6-month courses then every 3 months of treatment for at least two more years, with a dose of $0.75 \mathrm{mg} / \mathrm{m}^{2}$, and then adjusting the dose based on the nadir, 23 out of 46 women $(50 \%)$ developed amenorrhea [91]. In these studies, an age greater than 30 years and cumulative dose over $300 \mathrm{mg} / \mathrm{kg}$ were risk factors for persistent amenorrhea. The rate of amenorrhea in women with MS (approximately 40\%-80\% in large series) appears similar to that reported for rheumatic diseases [92]. Our data (unpublished) from more than 200 patients treated with the drug (alone or in combination with interferon-beta) showed a rate of irreversible ovarian failure of $18 \%$, while transient amenorrhea was observed in $60 \%$ of fertile woman (Table 3) [93]. A period of three-six months is considered, in clinical practice, the minimum period necessary to plan a pregnancy, after treatment with this drug, but, to date, there are no studies in the literature that can confirm the safety of this type of behavior in MS patients. However, three of our female patients with MS, after a mean period of 18 months from treatment with cy, became pregnant and have given birth to healthy babies. There are very few data concerning the frequency of infertility in men with immune-mediated diseases treated with cy. We evaluated the effect of cy on seminal fluid in nine MS patients (6 relapsing-remitting and 3 secondary progressive) treated for one year with the drug, with a median cumulative dosage of $22.100 \mathrm{mg}$ (5.100-40.100). At the end of treatment, the evaluation of sperm counts showed that $3(33 \%)$ patients were azoospermic, 2 (22\%) were oligospermic, and 4 (44\%) were normospermic (sperm count $>20 \mathrm{mil} / \mathrm{mL}$ ). All patients showed a decrease in spermatozoa motility $(<50 \%)$ and teratospermia (atypical form $>30 \%$ ). All oligospermic and azospermic patients presented higher serum levels of FSH and LH [94]. After one year of follow-up, we observed a recovery of the spermatogenesis in $60 \%$ of these patients.

An increased incidence of subsequent malignancies has been reported in non MS patients treated with cy. This event may occur a few years after cessation of therapy. The risk appears to increase as a function of total dose (care must be taken with cumulative lifetime doses exceeding 80$100 \mathrm{~g}$ ) [95]. De Ridder et al. observed bladder cancer in five patients out of $70(5.7 \%)$ treated with the drug and chronically catheterized. They suggested regular cystoscopy in these patients to allow early detection of bladder tumors [96]. Portaccio et al. assessed the safety and tolerability of cy "pulse" therapy, in 120 MS patients with progressive or very active MS who received intravenous monthly "pulses" of the drug for 12 months at the dosage of $700 \mathrm{mg} / \mathrm{m}^{2}$ of body surface, then bimonthly for another 12 months. They evaluated the frequency and the severity of side effects, most commonly definitive amenorrhea $33.3 \%$ of fertile women), hypogammaglobulinemia (5.4\%), and hemorrhagic cystitis $(4.5 \%)$. Malignancies were diagnosed in four $(3.6 \%)$ subjects, three of whom were previously treated with azathioprine [97]. As described above, Makhani and coworkers reviewed their multicentre experience with cy (cumulative dose between 1.60-72.70 g) in the treatment of 17 children with MS. The side effects observed were vomiting, transient alopecia, osteoporosis, amenorrhea, and a bladder carcinoma in one patient [71].

In our center, safety is monitored by obtaining blood and urine analyses every month and urine cytological examination every 3 months; bladder echography to evaluate an incomplete empting is obtained before and during treatment, ECG, chest radiography, echography of liver, spleen, kidney, bladder, uterus and lymph nodes, and mammography are performed every 12 months. Analysis of seminal fluid is obtained at the beginning and at the end of treatment. We suggest sperm cryopreservation or ovarian protection before cy treatment. We routinely administer a cumulative dose of about $30 \mathrm{~g}$ of the drug divided into monthly boosters over a period of one-two years. This treatment protocol is safe and well tolerated. It usually takes less than half of the cumulative recommended dose thus treatment can resume, if needed, in the course of the disease. Also, mitoxantrone cannot be administered safely for long periods. It appears that after 6-7 boosters, $70 \mathrm{mg} / \mathrm{m}^{2}$, mitoxantrone could increase the risk of cardiotoxicity and leukemia [98-105]. The use of natalizumab has raised some concerns about the risk of developing progressive multifocal leukoencephalopathy (PML). This risk is increased after 24-30 administrations and if patients had been previously treated with immunosuppressive agents [106-108]. However, the results observed from the patients included in the clinical trials and from the TOUCH prescribing program clearly indicate that the risk of PML during treatment with natalizumab is much lower than that of malignancies during treatment with cy (the risk ranged from $1 / 100.000$ for the first year of treatment until 
$1 / 1000$ after four years of treatment) [109, 110]. Little is known about the safe cumulative dosage of the new oral agents such as cladribine and fingolimod. However, safety profiles of both drugs raise several concerns, even if, to date, there are no indications about long-term toxicity [110-112].

\section{Conclusions and Future Investigations}

Based on the literature and on our experience, we suggest that cy could be a therapeutic option in MS patients, especially if they have an active inflammatory component. On the contrary, in later stages of the disease or in patients with primary progressive MS the effects of the drug are very poor. Its ineffectiveness in later stages of the disease, when there is less inflammation and more degenerative processes, appears to be true also for other drugs currently used in the treatment of the disease.

Given that early inflammatory events appear to correlate with later disability, a major question is whether strong antiinflammatory drugs such as cy or other drugs currently used to treat the disease will have an impact on later degenerative changes if given early in the disease to halt inflammation. With a better understanding of the pathogenesis of the disease, the possibility to identify new biomarkers and the introduction of pharmacogenomics and genetics in MS it may be possible to identify responders and nonresponders and provide them with a tailored therapy. Without this information, cy is, in our opinion, a possible treatment option for people with MS.

From the approval of mitoxantrone for worsening forms of MS the question remains of the place of cy in this patient group.

Mitoxantrone is considered easier to administer than cy. However, because of cardiac toxicity and the observed high frequency of iatrogenic leukemia, it can only be given for a limited period and cannot be given again if patients begin to reprogress. Cy can be used as a retreatment drug given that the cumulative dose limit is higher than that of mitoxantrone. However, bladder toxicity can strongly limit further therapy. For this reason, in our opinion, the use of cy or mitoxantrone depends, on the clinical condition of the organs suitable to be damaged by each drug (bladder and heart, respectively) and by the diligent monitoring over time of the patient's clinical conditions to identify and promptly treat any complications rather than on the cumulative dose. Furthermore, follow-up needs to be extended for many years following the treatment period to identify unknown long term side effects and to detect and treat, as soon as possible any that occur.

Sequential use of these agents has been carried out by some investigators, but toxicity profiles are unknown at this time.

We conclude that therapy with cy given in pulse therapy or in some instances as an acute induction regimen has an ameliorating effect on the disease process. It could be used in selected MS patient groups, and in "good hands" it could be used as induction regimen therapy in larger patient populations.

\section{References}

[1] M. B. Kastan, E. Schlaffer, J. E. Russo, O. M. Colvin, C. I. Civin, and J. Hilton, "Direct demonstration of elevated aldehyde dehydrogenase in human hematopoietic progenitor cells," Blood, vol. 75, no. 10, pp. 1947-1950, 1990.

[2] R. J. Jones, J. P. Barber, M. S. Vala et al., "Assessment of aldehyde dehydrogenase in viable cells," Blood, vol. 85, no. 10, pp. 2742-2746, 1995.

[3] R. A. Alarcon and J. Meienhofer, "Formation of the cytotoxic aldehyde acrolein during in vitro degradation of cyclophosphamide," Nature: New biology, vol. 233, no. 42, pp. 250-252, 1971.

[4] C. A. Langford, J. H. Klippel, J. E. Balow, S. P. James, and M. C. Sneller, "Use of cytotoxic agents and cyclosporine in the treatment of autoimmune disease. Part 1: rheumatologic and renal diseases," Annals of Internal Medicine, vol. 128, no. 12, pp. 1021-1028, 1998.

[5] C. A. Langford, J. H. Klippel, J. E. Balow, S. P. James, and M. C. Sneller, "Use of cytotoxic agents and cyclosporine in the treatment of autoimmune disease. Part 2: inflammatory bowel disease, systemic vasculitis, and therapeutic toxicity," Annals of Internal Medicine, vol. 129, no. 1, pp. 49-58, 1998.

[6] R. Zimmerman, J. Radhakrishnan, A. Valeri, and G. Appel, "Advances in the treatment of lupus nephritis," Annual Review of Medicine, vol. 52, pp. 63-78, 2001.

[7] C. A. Wallace and D. D. Sherry, "Trial of intravenous pulse cyclophosphamide and methylprednisolone in the treatment of severe systemic-onset juvenile rheumatoid arthritis," Arthritis and Rheumatism, vol. 40, no. 10, pp. 1852-1855, 1997.

[8] A. Schnabel, M. Reuter, and W. L. Gross, "Intravenous pulse cyclophosphamide in the treatment of interstitial lung disease due to collagen vascular diseases," Arthritis and Rheumatism, vol. 41, no. 7, pp. 1215-1220, 1998.

[9] N. C. Notermans, H. M. Lokhorst, H. Franssen et al., "Intermittent cyclophosphamide and prednisone treatment of polyneuropathy associated with monoclonal gammopathy of undetermined significance," Neurology, vol. 47, no. 5, pp. 1227-1233, 1996.

[10] J. L. Good, M. Chehrenama, R. F. Mayer, and C. Lee Koski, "Pulse cyclophosphamide therapy in chronic inflammatory demyelinating polyneuropathy," Neurology, vol. 51, no. 6, pp. 1735-1738, 1998.

[11] G. Aimard, P. F. Girard, and J. Raveau, "Multiple sclerosis and the autoimmunization process. Treatment by antimitotics," Lyon Medical, vol. 215, no. 6, pp. 345-352, 1966.

[12] S. J. Khoury, H. L. Weiner, and D. A. Hafler, "Immunological mechanisms in multiple sclerosis," in Handbook of Multiple Sclerosis, S. D. Cook, Ed., pp. 145-155, Marcel Dekker, New York, NY, USA, 1996.

[13] T. R. Mosmann, H. Cherwinski, and M. W. Bond, "Two types of murine helper T cell clone. I. Definition according to profiles of lymphokine activities and secreted proteins," Journal of Immunology, vol. 136, no. 7, pp. 2348-2357, 1986.

[14] Y. Chen, V. K. Kuchroo, J. Inobe, D. A. Hafler, and H. L. Weiner, "Regulatory T cell clones induced by oral tolerance: suppression of autoimmune encephalomyelitis," Science, vol. 265, no. 5176, pp. 1237-1240, 1994.

[15] D. G. Ando, J. Clayton, D. Kono, J. L. Urban, and E. E. Sercarz, "Encephalitogenic T cells in the B10.PL model of experimental allergic encephalomyelitis (EAE) are of the Th1 lymphokine subtype," Cellular Immunology, vol. 124, no. 1, pp. 132-143, 1989. 
[16] M. K. Racke, A. Bonomo, D. E. Scott et al., "Cytokineinduced immune deviation as a therapy for inflammatory autoimmune disease," Journal of Experimental Medicine, vol. 180, no. 5, pp. 1961-1966, 1994.

[17] S. J. Khoury, W. W. Hancock, and H. L. Weiner, "Oral tolerance to myelin basic protein and natural recovery from experimental autoimmune encephalomyelitis are associated with downregulation of inflammatory cytokines and differential upregulation of transforming growth factor $\beta$, interleukin 4, and prostaglandin E expression in the brain," Journal of Experimental Medicine, vol. 176, no. 5, pp. 13551364, 1992.

[18] M. K. Kennedy, D. S. Torrance, K. S. Picha, and K. M. Mohler, "Analysis of cytokine mRNA expression in the central nervous system of mice with experimental autoimmune encephalomyelitis reveals that IL-10 mRNA expression correlates with recovery," Journal of Immunology, vol. 149, no. 7, pp. 2496-2505, 1992.

[19] S. Issazadeh, AA. Ljungdahl, B. Hojeberg, M. Mustafa, and T. Olsson, "Cytokine production in the central nervous system of Lewis rats with experimental autoimmune encephalomyelitis: dynamics of mRNA expression for interleukin-10, interleukin-12, cytolysin, tumor necrosis factor $\alpha$ and tumor necrosis factor $\beta$," Journal of Neuroimmunology, vol. 61, no. 2, pp. 205-212, 1995.

[20] Y. Chen, W. W. Hancock, R. Marks, P. Gonnella, and H. L. Weiner, "Mechanisms of recovery from experimental autoimmune encephalomyelitis: $\mathrm{T}$ cell deletion and immune deviation in myelin basic protein $\mathrm{T}$ cell receptor transgenic mice," Journal of Neuroimmunology, vol. 82, no. 2, pp. 149159, 1998.

[21] R. Martin, H. F. McFarland, and D. E. McFarlin, "Immunological aspects of demyelinating diseases," Annual Review of Immunology, vol. 10, pp. 153-187, 1992.

[22] K. E. Balashov, J. B. Rottman, H. L. Weiner, and W. W. Hancock, "CCR5(+) and CXCR3(+) T cells are increased in multiple sclerosis and their ligands MIP- $1 \alpha$ and IP-10 are expressed in demyelinating brain lesions," Proceedings of the National Academy of Sciences of the United States of America, vol. 96, no. 12, pp. 6873-6878, 1999.

[23] A. Karni, D. N. Koldzic, P. Bharanidharan, S. J. Khoury, and H. L. Weiner, "IL-18 is linked to raised IFN- $\gamma$ in multiple sclerosis and is induced by activated CD4(+) T cells via CD40CD40 ligand interactions," Journal of Neuroimmunology, vol. 125, no. 1-2, pp. 134-140, 2002.

[24] J. Beck, P. Rondot, L. Catinot, E. Falcoff, H. Kirchner, and J. Wietzerbin, "Increased production of interferon gamma and tumor necrosis factor precedes clinical manifestation in multiple sclerosis: do cytokines trigger off exacerbations?" Acta Neurologica Scandinavica, vol. 78, no. 4, pp. 318-323, 1988.

[25] H. S. Panitch, R. L. Hirsch, A. S. Haley, and K. P. Johnson, "Exacerbations of multiple sclerosis in patients treated with gamma interferon," The Lancet, vol. 1, no. 8538, pp. 893-894, 1987.

[26] O. R. Hommes, F. Aerts, U. Bahr, and H. R. Schulten, "Cyclophosphamide levels in serum and spinal fluid of multiple sclerosis patients treated with immunosuppression," Journal of the Neurological Sciences, vol. 58, no. 2, pp. 297303, 1983.

[27] U. Bahr, H. R. Schulten, O. R. Hommes, and F. Aerts, "Determination of cyclophosphamide in urine, serum and cerebrospinal fluid of multiple sclerosis patients by field desorption mass spectrometry," Clinica Chimica Acta, vol. 103, no. 2, pp. 183-192, 1980.

[28] J. Chun and H. P. Hartung, "Mechanism of action of oral fingolimod (FTY720) in multiple sclerosis," Clinical Neuropharmacology, vol. 33, no. 2, pp. 91-101, 2010.

[29] J. Liliemark, "The clinical pharmacokinetics of cladribine," Clinical Pharmacokinetics, vol. 32, no. 2, pp. 120-131, 1997.

[30] R. J. M. Ten Berge, H. K. van Walbeek, and P. A. Schellekens, "Evaluation of the immunosuppressive effects of cyclophosphamide in patients with multiple sclerosis," Clinical and Experimental Immunology, vol. 50, no. 3, pp. 495-502, 1982.

[31] C. J. J. Brinkman, W. M. Nillesen, and O. R. Hommes, "T-cell subpopulations in blood and cerebrospinal fluid of multiple sclerosis patients: effect of cyclophosphamide," Clinical Immunology and Immunopathology, vol. 29, no. 3, pp. 341-348, 1983.

[32] D. J. Moody, J. Kagan, and D. Liao, "Administration of monthly-pulse cyclophosphamide in multiple sclerosis patients. Effects of long-term treatment on immunologic parameters," Journal of Neuroimmunology, vol. 14, no. 2, pp. 161-173, 1987.

[33] M. R. Mickey, G. W. Ellison, and J. L. Fahey, "Correlation of clinical and immunologic states in multiple sclerosis," Archives of Neurology, vol. 44, no. 4, pp. 371-375, 1987.

[34] D. R. Smith, K. E. Balashov, D. A. Hafler, S. J. Khoury, and H. L. Weiner, "Immune deviation following pulse cyclophosphamide/methylprednisolone treatment of multiple sclerosis: increased interleukin-4 production and associated eosinophilia," Annals of Neurology, vol. 42, no. 3, pp. 313-318, 1997.

[35] H. Takashima, D. R. Smith, H. Fukaura, S. J. Khoury, D. A. Hafler, and H. L. Weiner, "Pulse cyclophosphamide plus methylprednisolone induces myelin-antigen- specific IL-4secreting $\mathrm{T}$ cells in multiple sclerosis patients," Clinical Immunology and Immunopathology, vol. 88, no. 1, pp. 28-34, 1998.

[36] B. M. J. Uitdehaag, W. M. Nillesen, and O. R. Hommes, "Long-lasting effects of cyclophosphamide on lymphocytes in peripheral blood and spinal fluid," Acta Neurologica Scandinavica, vol. 79, no. 1, pp. 12-17, 1989.

[37] B. K. A. Padmanabhan, W. Hanock, S. Khoury, and H. L. Weiner, "Effect of cyclophosphamide pulse therapy on chemokine receptor expression in patients with multiple sclerosis," Neurology, vol. A226, 2001.

[38] R. Manetti, P. Parronchi, M. G. Giudizi et al., "Natural killer cell stimulatory factor (interleukin 12 [IL-12]) induces $\mathrm{T}$ helper type 1 (Th1)-specific immune responses and inhibits the development of IL-4-producing Th cells," Journal of Experimental Medicine, vol. 177, no. 4, pp. 1199-1204, 1993.

[39] R. Manetti, F. Gerosa, M. G. Giudizi et al., "Interleukin 12 induces stable priming for interferon gamma (IFN-gamma) production during differentiation of human $\mathrm{T}$ helper (Th) cells and transient IFN-gamma production in established Th2 cell clones," The Journal of Experimental Medicine, vol. 179, pp. 1273-1283, 1994.

[40] R. A. Seder, R. Gazzinelli, A. Sher, and W. E. Paul, "Interleukin 12 acts directly on CD4+ T cells to enhance priming for interferon $\gamma$ production and diminishes interleukin 4 inhibition of such priming," Proceedings of the National Academy of Sciences of the United States of America, vol. 90, no. 21, pp. 10188-10192, 1993. 
[41] C. S. Hsieh, S. E. Macatonia, C. S. Tripp, S. F. Wolf, A. O'Garra, and K. M. Murphy, "Development of T(H)1 CD41 T cells through IL-12 produced by Listeria-induced macrophages," Science, vol. 260, no. 5107, pp. 547-549, 1993.

[42] J. P. Leonard, K. E. Waldburger, S. J. Goldman, and H. W. Murray, "Prevention of experimental autoimmune encephalomyelitis by antibodies against interleukin 12," Journal of Experimental Medicine, vol. 181, no. 1, pp. 381386, 1995.

[43] K. E. Balashov, D. R. Smith, S. J. Khoury, D. A. Hafler, and H. L. Weiner, "Increased interleukin 12 production in progressive multiple sclerosis: induction by activated CD41 T cells via CD40 ligand," Proceedings of the National Academy of Sciences of the United States of America, vol. 94, no. 2, pp. 599-603, 1997.

[44] F. Nicoletti, F. Patti, C. Cocuzza et al., "Elevated serum levels of interleukin-12 in chronic progressive multiple sclerosis," Journal of Neuroimmunology, vol. 70, no. 1, pp. 87-90, 1996.

[45] K. E. Balashov, D. R. Smith, S. J. Khoury, D. A. Hafler, and H. L. Weiner, "Increased interleukin 12 production in progressive multiple sclerosis: induction by activated CD4+ T cells via CD40- ligand," Proceedings of the National Academy of Sciences of the United States of America, vol. 94, no. 2, pp. 599-603, 1997.

[46] M. Comabella, K. Balashov, S. Issazadeh, D. Smith, H. L. Weiner, and S. J. Khoury, "Elevated interleukin-12 in progressive multiple sclerosis correlates with disease activity and is normalized by pulse cyclophosphamide therapy," Journal of Clinical Investigation, vol. 102, no. 4, pp. 671-678, 1998.

[47] L. La Mantia, C. Milanese, N. Mascoli, R. D’Amico, and B. Weinstock-Guttman, "Cyclophosphamide for multiple sclerosis," Cochrane Database of Systematic Reviews, no. 1, Article ID CD002819, 2007.

[48] A. Boster, G. Edan, E. Frohman et al., "Intense immunosuppression in patients with rapidly worsening multiple sclerosis: treatment guidelines for the clinician," The Lancet Neurology, vol. 7, no. 2, pp. 173-183, 2008.

[49] R. Gross and G. Wulf, "Klinische und experimentelle Erfahrungen mit zyk lischen und nichtzyklischen Phosphamidestern des N-Losl in der Chemotherapie von Tumoren," Strahlentherapie, vol. 41, Sonderband III, pp. 361367, 1959.

[50] P. F. Girard, G. Aimard, and H. Pellet, "Thérapeutique immuno-dépressive en neurologie," La Presse medicale, vol. 75, no. 19, pp. 967-968, 1967.

[51] P. Millac and H. Miller, "Cyclophosphamide in multiple sclerosis," The Lancet, vol. 1, no. 7598, p. 783, 1969.

[52] V. Weiczorek and W. Brodkorb, "Erfahrungen mit der immunosuppressive Behandlung der Multiplen Sklerose mit Cyclosphamid und Imuran,” Disch Ges Wesen, vol. 26, pp. 1791-1794, 1971.

[53] W. Göpel, H. Benkenstein, and M. Banzhaf, "Immunosuppressive therapy of multiple sclerosis using cyclophosphamide and imuran. Report on 57 cases," Deutsche Gesundheitswesen, vol. 27, no. 41, pp. 1955-1961, 1972.

[54] W. Cendrowski, "Combined therapeutic trial in multiple sclerosis: hydrocortisone hemisuccinate with cyclophosphamide or cytosine arabinoside," Acta Neurologica Belgica, vol. 73, no. 4, pp. 209-219, 1973.

[55] O. R. Hommes, J. J. G. Prick, and K. J. B. Lamers, “Treatment of the chronic progressive form of multiple sclerosis with a combination of cyclophosphamide and prednisone," Clinical Neurology and Neurosurgery, vol. 78, no. 1, pp. 59-73, 1975.
[56] D. A. Drachman, P. Y. Paterson, R. T. Schmidt, and R. F. Spehlmann, "Cyclophosphamide in exacerbations of multiple sclerosis. Therapeutic trial and a strategy for pilot drug studies," Journal of Neurology Neurosurgery and Psychiatry, vol. 38, no. 6, pp. 592-597, 1975.

[57] R. E. Gonsette, L. Demonty, and P. Delmotte, "Intensive immunosuppression with cyclophosphamide in multiple sclerosis. Follow up of 110 patients for 2 to 6 years," Journal of Neurology, vol. 214, no. 3, pp. 173-181, 1977.

[58] S. L. Hauser, D. M. Dawson, and J. R. Lehrich, "Intensive immunosuppression in progressive multiple sclerosis. A randomized, three-arm study of high-dose intravenous cyclophosphamide, plasma exchange, and ACTH," The New England Journal of Medicine, vol. 308, no. 4, pp. 173-180, 1983.

[59] H. L. Weiner, G. A. Mackin, E. J. Orav et al., "Intermittent cyclophosphamide pulse therapy in progressive multiple sclerosis: final report of the Northeast Cooperative Multiple Sclerosis Treatment Group," Neurology, vol. 43, no. 5, pp. 910-918, 1993.

[60] J. H. Noseworthy, G. C. Ebers, M. Gent et al., "The Canadian cooperative trial of cyclophosphamide and plasma exchange in progressive multiple sclerosis," The Lancet, vol. 337, no. 8739, pp. 441-446, 1991.

[61] W. H. Likosky, B. Fireman, R. Elmore et al., "Intense immunosuppression in chronic progressive multiple sclerosis: the Kaiser study," Journal of Neurology Neurosurgery and Psychiatry, vol. 54, no. 12, pp. 1055-1060, 1991.

[62] J. H. Noseworthy, G. C. Ebers, R. Roberts et al., "Cyclophosphamide and MS-letter to the editor," Neurology, vol. 44, no. 3 I, pp. 579-581, 1994.

[63] J. H. Noseworthy, M. K. Vandervoort, M. Penman et al., "Cyclophosphamide and plasma exchange in multiple sclerosis," The Lancet, vol. 337, no. 8756, pp. 1540-1541, 1991.

[64] B. O. Khatri, M. P. McQuillen, R. G. Hoffmann et al., "Cyclophosphamide and plasma exchange in multiple sclerosis," The Lancet, vol. 337, no. 8748, pp. 1033-1034, 1991.

[65] B. Weinstock-Guttman, R. P. Kinkel, J. A. Cohen et al., "Treatment of fulminant multiple sclerosis with intravenous cyclophosphamide," Neurologist, vol. 3, no. 3, pp. 178-185, 1997.

[66] M. I. Gobbini, M. E. Smith, N. D. Richert, J. A. Frank, and H. F. McFarland, "Effect of open label pulse cyclophosphamide therapy on MRI measures of disease activity in five patients with refractory relapsing-remitting multiple sclerosis," Journal of Neuroimmunology, vol. 99, no. 1, pp. 142-149, 1999.

[67] O. A. Khan, M. Zvartau-Hind, C. Caon et al., "Effect of monthly intravenous cyclophosphamide in rapidly deteriorating multiple sclerosis patients resistant to conventional therapy," Multiple Sclerosis, vol. 7, no. 3, pp. 185-188, 2001.

[68] P. R. M. De Bittencourt and M. M. Gomes-Da-Silva, "Multiple sclerosis: long-term remission after a high close of cyclophosphamide," Acta Neurologica Scandinavica, vol. 111, no. 3, pp. 195-198, 2005.

[69] D. E. Gladstone, K. W. Zamkoff, L. Krupp et al., "High-dose cyclophosphamide for moderate to severe refractory multiple sclerosis," Archives of Neurology, vol. 63, no. 10, pp. 13881393, 2006.

[70] C. Krishnan, A. I. Kaplin, R. A. Brodsky et al., "Reduction of disease activity and disability with high-dose cyclophosphamide in patients with aggressive multiple sclerosis," Archives of Neurology, vol. 65, no. 8, pp. 1044-1051, 2008. 
[71] N. Makhani, M. P. Gorman, H. M. Branson, L. Stazzone, B. L. Banwell, and T. Chitnis, "Cyclophosphamide therapy in pediatric multiple sclerosis," Neurology, vol. 72, no. 24, pp. 2076-2082, 2009.

[72] V. Zipoli, E. Portaccio, B. Hakiki, G. Siracusa, S. Sorbi, and M. Pia Amato, "Intravenous mitoxantrone and cyclophosphamide as second-line therapy in multiple sclerosis: an open-label comparative study of efficacy and safety," Journal of the Neurological Sciences, vol. 266, no. 1-2, pp. 25-30, 2008.

[73] P. Perini, M. Calabrese, M. Tiberio, F. Ranzato, L. Battistin, and P. Gallo, "Mitoxantrone versus cyclophosphamide in secondary-progressive multiple sclerosis: a comparative study," Journal of Neurology, vol. 253, no. 8, pp. 1034-1040, 2006.

[74] F. Patti, M. L. Cataldi, F. Nicoletti, E. Reggio, A. Nicoletti, and A. Reggio, "Combination of cyclophosphamide and interferon- $\beta$ halts progression in patients with rapidly transitional multiple sclerosis," Journal of Neurology Neurosurgery and Psychiatry, vol. 71, no. 3, pp. 404-407, 2001.

[75] F. Patti, E. Reggio, F. Palermo et al., "Stabilization of rapidly worsening multiple sclerosis for 36 months in patients treated with interferon beta plus cyclophosphamide followed by interferon beta," Journal of Neurology, vol. 251, no. 12, pp. 1502-1506, 2004.

[76] E. Reggio, A. Nicoletti, T. Fiorilla, G. Politi, A. Reggio, and F. Patti, "The combination of cyclophosphamide plus interferon beta as rescue therapy could be used to treat relapsing-remitting multiple sclerosis patients: twenty-four months follow-up," Journal of Neurology, vol. 252, no. 10, pp. 1255-1261, 2005.

[77] D. R. Smith, B. Weinstock-Guttman, J. A. Cohen et al., "A randomized blinded trial of combination therapy with cyclophosphamide in patients with active multiple sclerosis on interferon beta," Multiple Sclerosis, vol. 11, no. 5, pp. 573582, 2005.

[78] F. Patti, S. Lo Fermo, E. D’Amico, S. Messina, T. Cavallaro, and M. Zappia, "Comparison of two therapeutic strategies in active relapsing-remitting MS: cyclophosphamide as induction for 12 months followed by interferon beta versus interferon beta. A 2-year randomized trial," in Procedings of the 61st Annual Meeting of thr American Academy of Neurology (AAN '09), Therapeutics II, Seattle, Wash, USA, April 2009, Poster Session VII: Multiple Sclerosis.

[79] J. S. Perumal, S. Hreha, C. Caon et al., "Long-term efficacy and safety of intense immunosuppression as first line therapy in clinically active relapsing MS: a new treatment algorithm," in Procedings of the 61st Annual Meeting of thr American Academy of Neurology (AAN '09), Therapeutics II, Seattle, Wash, USA, April 2009, Poster Session VII: Multiple Sclerosis.

[80] D. W. Van Bekkum, "Stem cell transplantation in experimental models of autoimmune disease," Journal of Clinical Immunology, vol. 20, no. 1, pp. 10-16, 2000.

[81] E. Carreras, A. Saiz, P. Marín et al., "CD34+ selected autologous peripheral blood stem cell transplantation for multiple sclerosis: report of toxicity and treatment results at one year of follow-up in 15 patients," Haematologica, vol. 88, no. 3, pp. 306-314, 2003.

[82] A. Fassas, A. Anagnostopoulos, A. Kazis et al., "Autologous stem cell transplantation in progressive multiple sclerosisan interim analysis of efficacy," Journal of Clinical Immunology, vol. 20, no. 1, pp. 24-30, 2000.
[83] G. L. Mancardi, R. Saccardi, M. Filippi et al., "Autologous hematopoietic stem cell transplantation suppresses Gdenhanced MRI activity in MS," Neurology, vol. 57, no. 1, pp. 62-68, 2001.

[84] R. A. Nash, J. D. Bowen, P. A. McSweeney et al., "Highdose immunosuppressive therapy and autologous peripheral blood stem cell transplantation for severe multiple sclerosis," Blood, vol. 102, no. 7, pp. 2364-2372, 2003.

[85] A. S. Fassas, J. R. Passweg, A. Anagnostopoulos et al., "Hematopoietic stem cell transplantation for multiple sclerosis: a retrospective multicenter study," Journal of Neurology, vol. 249, no. 8, pp. 1088-1097, 2002.

[86] R. J. Bernacki, S. K. Bansal, and H. L. Gurtoo, "Combinations of mesna with cyclophosphamide or Adriamycin in the treatment of mice with tumors," Cancer Research, vol. 47, no. 3, pp. 799-802, 1987.

[87] M. F. Gourley, H. A. Austin, D. Scott et al., "Methylprednisolone and cyclophosphamide, alone or in combination, in patients with lupus nephritis. A randomized controlled trial," Annals of Internal Medicine, vol. 125, no. 7, pp. 549$557,1996$.

[88] T. J. Stillwell and R. C. Benson, "Cyclophosphamide-induced hemorrhagic cystitis. A review of 100 patients," Cancer, vol. 61, no. 3, pp. 451-457, 1988.

[89] C. Talar-Williams, Y. M. Hijazi, M. M. Walther et al., "Cyclophosphamide-induced cystitis and bladder cancer in patients with Wegener granulomatosis," Annals of Internal Medicine, vol. 124, no. 5, pp. 477-484, 1996.

[90] C. D. Radis, L. E. Kahl, G. L. Baker et al., "Effects of cyclophosphamide on the development of malignancy and on long- term survival of patients with rheumatoid arthritis: a 20-year followup study," Arthritis and Rheumatism, vol. 38, no. 8, pp. 1120-1127, 1995.

[91] D. T. Boumpas, H. A. Austin, E. M. Vaughan, C. H. Yarboro, J. H. Klippel, and J. E. Balow, "Risk for sustained amenorrhea in patients with systemic lupus erythematosus receiving intermittent pulse cyclophosphamide therapy," Annals of Internal Medicine, vol. 119, no. 5, pp. 366-369, 1993.

[92] C. A. Slater, M. H. Liang, J. W. McCune, G. M. Christman, and M. R. Laufer, "Preserving ovarian function in patients receiving cyclophosphamide," Lupus, vol. 8, no. 1, pp. 3-10, 1999.

[93] S. Lo Fermo, P. Laisa, T. L. Cavallaro et al., "Long term followup of combination therapy with INF- $\beta$; and cyclophosphamide in relapsing-remitting MS patients," in Proceedings of the 38th Annual Meeting of the Italian Neurological Society, 2007, Oral comunication: Multiple Sclerosis.

[94] S. Lo Fermo, S. La Vignera, P. Laisa et al., "Detrimental effects of cyclophosphamide on seminal cells in men with MS," in Proceedings of the XL Annual Meeting of the Italian Neurological Society, 2009, Poster Session: Multiple Sclerosis.

[95] C. Talar-Williams, Y. M. Hijazi, M. M. Walther et al., "Cyclophosphamide-induced cystitis and bladder cancer in patients with Wegener granulomatosis," Annals of Internal Medicine, vol. 124, no. 5, pp. 477-484, 1996.

[96] D. De Ridder, H. Van Poppel, L. Demonty et al., "Bladder cancer in patients with multiple sclerosis treated with cyclophosphamide," Journal of Urology, vol. 159, no. 6, pp. 1881-1884, 1998.

[97] E. Portaccio, V. Zipoli, G. Siracusa, S. Piacentini, S. Sorbi, and M. P. Amato, "Safety and tolerability of cyclophosphamide 'pulses' in multiple sclerosis: a prospective study in a clinical cohort," Multiple Sclerosis, vol. 9, no. 5, pp. 446-450, 2003. 
[98] E. Kingwell, M. Koch, B. Leung et al., "Cardiotoxicity and other adverse events associated with mitoxantrone treatment for MS," Neurology, vol. 74, no. 22, pp. 1822-1826, 2010.

[99] V. Martinelli, M. Radaelli, L. Straffi, M. Rodegher, and G. Comi, "Mitoxantrone: benefits and risks in multiple sclerosis patients," Neurological Sciences, vol. 30, no. 2, pp. S167-S170, 2009.

[100] J. J. Marriott, J. M. Miyasaki, G. Gronseth, and P. W. O'Connor, "Evidence report: the efficacy and safety of mitoxantrone (Novantrone) in the treatment of multiple sclerosis: report of the Therapeutics and Technology Assessment Subcommittee of the American Academy of Neurology," Neurology, vol. 74, no. 18, pp. 1463-1470, 2010.

[101] A. M. Pascual, N. Téllez, I. Boscá et al., "Revision of the risk of secondary leukaemia after mitoxantrone in multiple sclerosis populations is required," Multiple Sclerosis, vol. 15, no. 11, pp. 1303-1310, 2009.

[102] R. Ellis and M. Boggild, "Therapy-related acute leukaemia with Mitoxantrone: what is the risk and can we minimise it?" Multiple Sclerosis, vol. 15, no. 4, pp. 505-508, 2009.

[103] I. Bosca, A. M. Pascual, B. Casanova, F. Coret, and M. A. Sanz, "Four new cases of therapy-related acute promyelocytic leukemia after mitoxantrone," Neurology, vol. 71, no. 6, pp. 457-458, 2008.

[104] C. Warnke, T. Menge, H.-P. Hartung et al., "Natalizumab and progressive multifocal leukoencephalopathy: what are the causal factors and can it be avoided?" Archives of Neurology, vol. 67, no. 8, pp. 923-930, 2010.

[105] J. R. Berger, D. Centonze, G. Comi et al., "Considerations on discontinuing natalizumab for the treatment of multiple sclerosis," Annals of Neurology, vol. 68, no. 3, pp. 409-411, 2010.

[106] T. W. West and B. A.C. Cree, "Natalizumab dosage suspension: are we helping or hurting?" Annals of Neurology, vol. 68, no. 3, pp. 395-399, 2010.

[107] G. Giovannoni, G. Comi, S. Cook et al., "A placebocontrolled trial of oral cladribine for relapsing multiple sclerosis," The New England Journal of Medicine, vol. 362, no. 5, pp. 416-426, 2010.

[108] J. A. Cohen, F. Barkhof, G. Comi et al., "Oral fingolimod or intramuscular interferon for relapsing multiple sclerosis," The New England Journal of Medicine, vol. 362, no. 5, pp. 402415, 2010.

[109] T. A. Yousry, E. O. Major, C. Ryschkewitsch et al., "Evaluation of patients treated with natalizumab for progressive multifocal leukoencephalopathy," The New England Journal of Medicine, vol. 354, no. 9, pp. 924-933, 2006.

[110] “The Tysabri TOUCH prescribing program," https://medinfo .biogenidec.com/.

[111] K. W. Rammohan and J. Shoemaker, "Emerging multiple sclerosis oral therapies," Neurology, vol. 74, pp. S47-S53, 2010.

[112] C. Gasperini, S. Ruggieri, and C. Pozzilli, "Emerging oral treatments in multiple sclerosis-clinical utility of cladribine tablets," Journal of Therapeutics and Clinical Risk Management, vol. 6, pp. 391-399, 2010. 


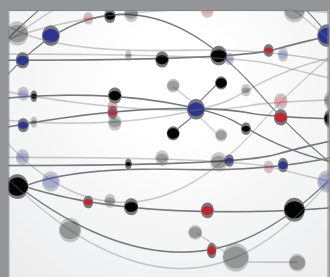

The Scientific World Journal
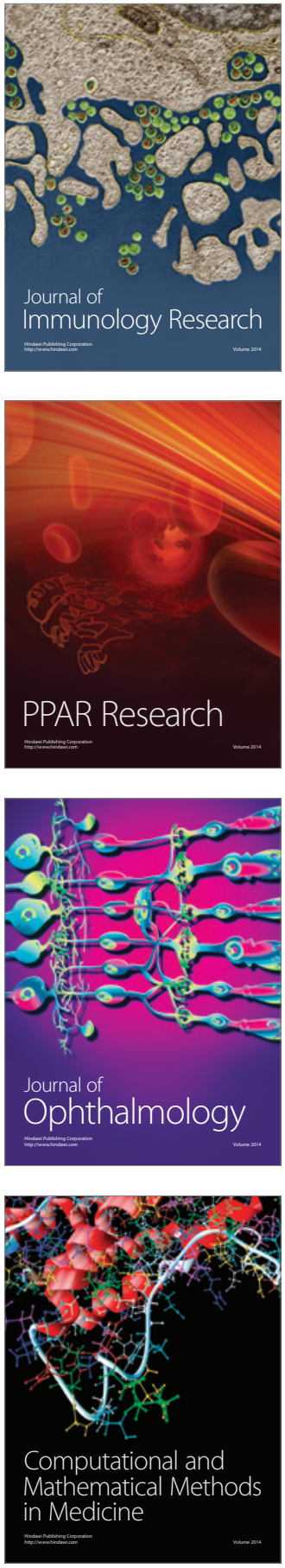

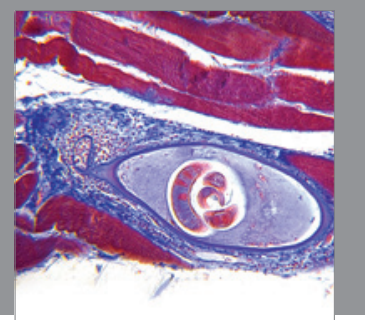

Gastroenterology

Research and Practice
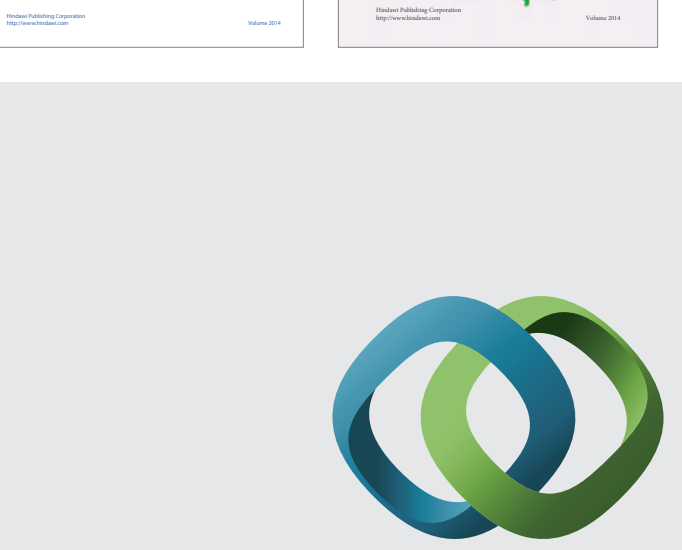

\section{Hindawi}

Submit your manuscripts at

http://www.hindawi.com
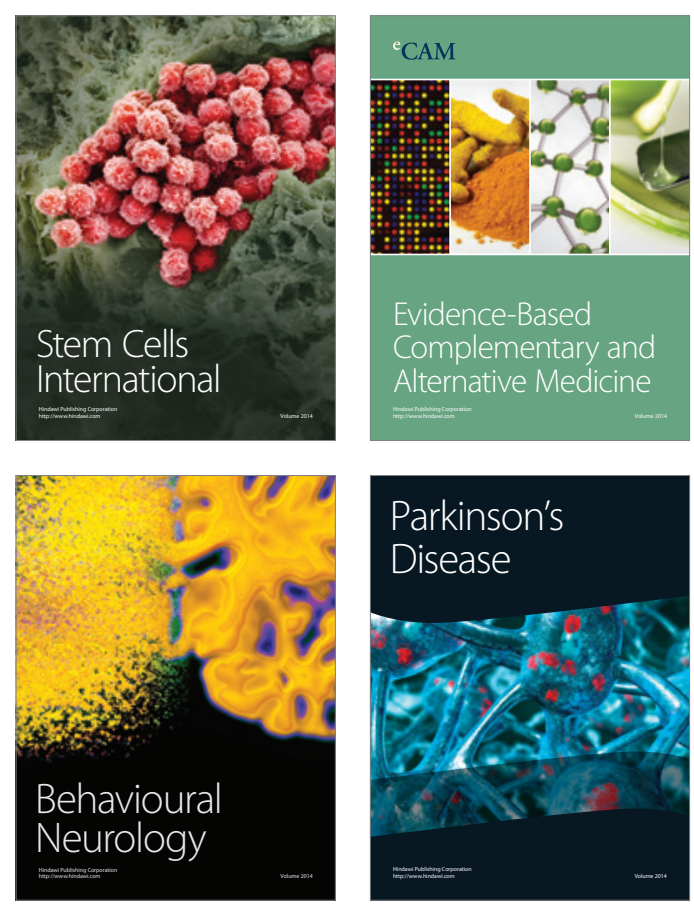

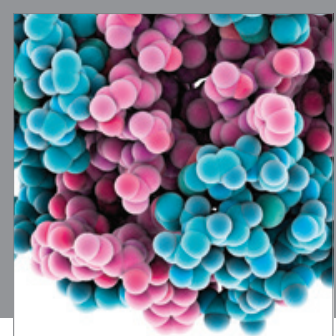

Journal of
Diabetes Research

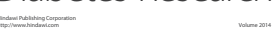

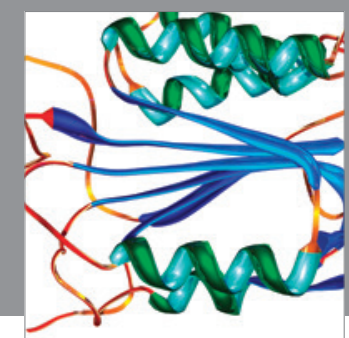

Disease Markers
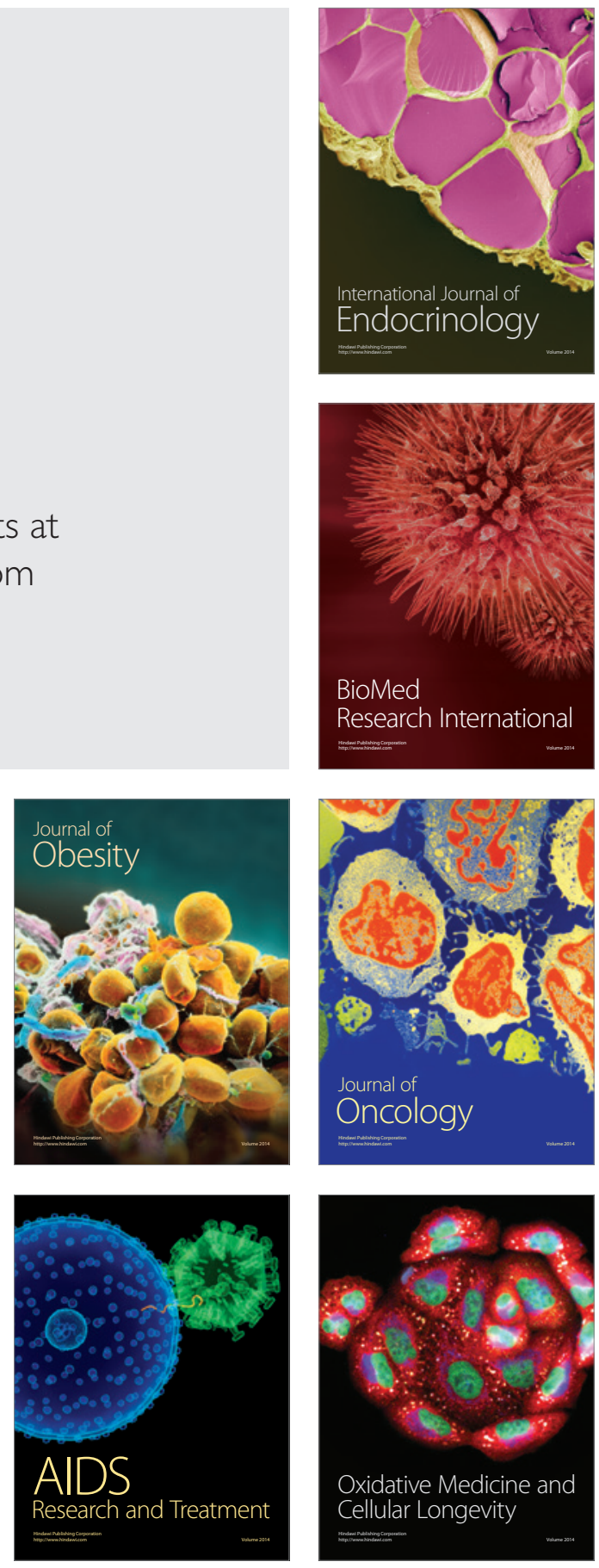